\title{
IDENTIFICATION OF BRCA1/2 MUTATIONS IN BREAST CANCER PATIENTS BY NEXT-GENERATION SEQUENCING
}

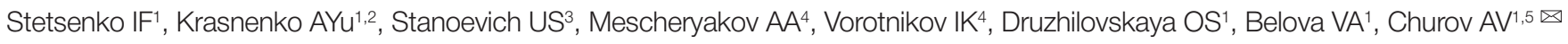 \\ 1 Vavilov Institute of General Genetics of the Russian Academy of Sciences, Moscow \\ ${ }^{2}$ Genotek Ltd., Moscow \\ ${ }^{3}$ Russian Scientific Center for X-ray Radiology of the Ministry of Health of the Russian Federation, Moscow \\ ${ }^{4}$ Blokhin Russian Cancer Research Centre, Moscow \\ ${ }^{5}$ IB KarRC RAS, Petrozavodsk
}

Breast cancer is one of the most widespread forms of solid tumors. By analyzing the traits of breast cancer pathogenesis at the molecular level using modern genetic analysis techniques and at different stages of the disease new data can be obtained to be further utilized in clinical practice. Molecular profiling based on next-generation sequencing is being increasingly applied as a clinical test to select target drugs for treating breast cancer patients with tumors highly resistant to therapy. In this study, we performed targeted sequencing of BRCA1 and BRCA2 oncogenes. In the total of 66 DNA samples from patients with breast tumors, BRCA1/2 mutations were found in 39 patients. There were 78 unique genetic variants, including 30 mutations in $B R C A 1$ and 48 mutations in BRCA2. We identified 33 mutations affecting the sites of post-translational modification in proteins (PMT mutations).

Keywords: BRCA1, BRCA2, breast cancer, NGS, DNA-sequencing, mutation, personalized medicine

Funding: this work was supported by the Ministry of Education and Science of the Russian Federation (Project ID RFMEFI60716X0152).

$\triangle$ Correspondence should be addressed: Alexey V. Churov

Pushkinskaya 11, Petrozavodsk,185910; achurou@yandex.ru

Received: 03.12.2018 Accepted: 14.12 .2018

DOI: $10.24075 /$ brsmu.2018.074

\section{ИДЕНТИФИКАЦИЯ ВRСА1/2-МУТАЦИЙ ПРИ РАКЕ МОЛОЧНОЙ ЖЕЛЕЗЫ С ПРИМЕНЕНИЕМ ТЕХНОЛОГИИ ВЫСОКОПРОИЗВОДИТЕЛЬНОГО СЕКВЕНИРОВАНИЯ}

И. Ф. Стеценко ${ }^{1}$ А. Ю. Красненко ${ }^{1,2}$, У. С. Станоевич ${ }^{3}$, А. А. Мещеряков ${ }^{4}$, И. К. Воротников ${ }^{4}$, О. С. Дружиловская ${ }^{1}$

В. А. Белова ${ }^{1}$, А. В. Чуров $1,5 \square$

${ }^{1}$ Институт общей генетики имени Н. И. Вавилова РАН, Москва

2 ООО «Генотек», Москва

${ }^{3}$ Российский научный центр рентгенорадиологии МЗ РФ, Москва

${ }^{4}$ Национальный медицинский исследовательский центр онкологии имени Н. Н. Блохина, Москва

${ }^{5}$ Институт биологии, Карельский научный центр (ИБ КарНЦ РАН), Петрозаводск

\begin{abstract}
Рак молочной железы (РМЖ) является одной из наиболее распространенных форм солидных опухолей. Анализ особенностей патогенеза РМЖ на молекулярном уровне с применением современных методов генетического анализа и на разных стадиях заболевания позволяет получить новые данные для их дальнейшего применения в клинической практике. Молекулярное профилирование с применением технологий высокопроизводительного секвенирования все чаще применяют в качестве клинического теста при подборе таргетных препаратов для лечения пациентов с высокорезистентными к терапии опухолями при РМЖ. Целью работы было провести таргетное секвенирование генов BRCA1 и BRCA2 в составе панели онкогенов. Из 66 образцов ДНК пациентов с опухолями молочной железы, мутации BRCA1/2 обнаружены у 39 пацентов. Найдено 78 уникальных генетических вариантов, из них 30 мутаций в гене BRCA1 и 48 мутаций в гене BRCA2. Идентифицировано 33 мутации, оказывающие влияние на сайты посттрансляционной модификации белков (РМТ-мутации).
\end{abstract}

Ключевые слова: BRCA1, BRCA2, рак молочной железы, NGS, ДНК-секвенирование, мутация, персонализированная медицина

Финансирование: работа выполнена при финансовой поддержке государства в лице Минобрнауки России (идентификатор соглашения RFMEFI60716Х0152).

$\triangle$ Для корреспонденции: Алексей Викторович Чуров

ул. Пушкинская, д. 11, г. Петрозаводск, 185035; achurou@yandex.ru

Статья получена: 03.12.2018 Статья принята к печати: 14.12.2018

DOI: 10.24075/vrgmu.2018.074

Breast cancer $(\mathrm{BC})$ is one of the most widespread forms of malignant neoplasms, next only to lung cancer and colorectal cancer. BC incidence has been growing in many parts of the world [1-4]. Early detection of the pathology and screening for $\mathrm{BC}$ is therefore a key task.
Suppressor genes BRCA1 and BRCA2 are important actors in regulating the signaling pathways associated with the functioning of DNA repair systems. Mutations in these genes entail an elevated risk of developing $\mathrm{BC}$ and some other forms of malignant tumors. 
A substantial proportion of the mutations in tumors are somatic mutations, playing an important role both in the pathogenesis of sporadic BC and in the development of de novo resistance to anticancer drugs. Sporadic forms of cancer constitute, on average, $70-80 \%$ of $\mathrm{BC}$ cases, whereas only $10 \%$ of all the patients carry inherited mutations in the BRCA1 and BRCA2 genes [5].

The actual task of oncogenetics today is the development and improvement of approaches to the effective selection of anticancer drugs, taking into account the molecular-genetic features of tumor development.

The aim of this study was to identify the spectrum of mutations in the BRCA1 and BRCA2 genes in patients with $B C$ by Illumina next-generation sequencing.

\section{METHODS}

\section{Material for the study. Clinical characteristics of the patients}

The collection of tumor samples for the study was taken from 66 patients with malignant breast neoplasms in hospital care at NN Blokhin National Medical Research Centre of Oncology of the Russian Health Ministry and Russian Scientific Center for X-ray Radiology of the Ministry of Health of the Russian Federation, (Moscow). The average age of the patients was $52.5 \pm 9.7$ years. The criteria for being included in the study were: age of 18 to 70, female, clinically verified BC diagnosis. Exclusion criteria: history of other forms of neoplasms, pregnancy. BC was staged according to TNM classification [6]. The study involved patients with stages $\mathrm{T} 1-3 \mathrm{NO}-3 \mathrm{MO}-1$. The study adhered to the principles of voluntariness and confidentiality. All patients provided informed consent to the study. The principal clinical characteristics of the patients are given in Table 1.

\section{DNA isolation and quality control. Oncogene panel sequencing}

Genomic DNA was isolated from tumor tissue samples by using DNeasy Blood and Tissue Kit (Qiagen; USA) as instructed by the manufacturer. The concentration of the extracted DNA specimens was measured with a Qubit 3.0 fluorometer (Thermo Fisher Scientific; USA). The quality of the DNA samples was additionally tested by electorphoresis in 1\% agarose gel with ethidium bromide.

DNA fragment libraries were prepared using NEBNext Ultra DNA Library Prep Kit for Illumina (New England Biolabs; USA). The libraries were barcoded by PCR using two reagent kits: NEBNext Ultra DNA Library Prep Kit for Illumina and NEBNext Multiplex Oligos for Illumina (Dual Index Primers Set 1, New England Biolabs; USA). DNA library quality control was done by measurements with Agilent Bioanalyzer 2100 (Agilent Technologies; USA) using High Sensitivity Kit as instructed by the manufacturer.

Coding regions of the tumor genome were enriched using MYbaits Onconome KL v1.5 Panel (Mycroarray; USA). The analysis was performed with a high-throughput genome sequencing system HiSeq 2500 (Illumina; USA) using paired 100-nucleotide reads. The samples were prepared and initiated according to Illumina protocols.

\section{Bioinformatic processing of NGS data}

Bioinformatic processing of the resultant NGS data was carried out using a previously developed algorithm [7, 8]. At first, the quality of the reads from DNA sequencing was assessed by Cutadapt software, and they were mapped to the reference genome hg19 (GRCh37.p13) by using the BWA tool (Burrows-

Table 1. Clinical characteristics of women with breast cancer $(n=66)$

\begin{tabular}{|c|c|}
\hline Parameter & Value, abs. no (\%) \\
\hline Age (years) & $52.5 \pm 9.7$ \\
\hline \multicolumn{2}{|l|}{ Principal diagnosis: } \\
\hline Left breast cancer & $32(48.5)$ \\
\hline Right breast cancer & $32(48.5)$ \\
\hline Bilateral cancer & $2(3)$ \\
\hline \multicolumn{2}{|l|}{ Tumor T-stage (TNM classification): } \\
\hline T1 & $36(54.5)$ \\
\hline T2 & $29(43.9)$ \\
\hline T3 & $1(1.5)$ \\
\hline \multicolumn{2}{|l|}{ Metastases in lymph nodes: } \\
\hline without metastases, M0 & $56(84.8)$ \\
\hline with metastases, M1 & $10(15.2)$ \\
\hline \multicolumn{2}{|l|}{ Expression of estrogen receptors (ER): } \\
\hline ER+ & $53(80.3)$ \\
\hline ER- & 13(19.7) \\
\hline \multicolumn{2}{|l|}{ Expression of progesterone receptors (PR): } \\
\hline $\mathrm{PR}+$ & $50(75.8)$ \\
\hline PR- & $16(24.2)$ \\
\hline \multicolumn{2}{|l|}{ Expression of HER2/neu (Cerb-B2): } \\
\hline Her2+ & $38(57.6)$ \\
\hline Her2- & $28(42.4)$ \\
\hline
\end{tabular}

Note: the values are in $\mathrm{M} \pm \mathrm{SD}$ or \% form; T 1-3 - tumor stages according to TNM classification; ER — estrogen receptor expression; PR — progesterone receptor expression; HER2/neu (Cerb-B2) - expression of the human epidermal growth factor receptor 2 . 
Wheeler Aligner). Paired reads were removed by running the specialized rmdup command in the SAMtools software package. Mutations in the NGS dataset were detected by MuTect, and DNA sequences covered by at least 12 readswere considered the most significant.

The mutation abundance was defined as the proportion (\%) of mutation-supporing reads at a position. The functional effect of the mutations was assessed relying on ActiveDriverDB database [9]. The mutations affecting the coded protein were visualized using the ProteinPaint application [10].

\section{RESULTS}

We analyzed DNA samples from breast tumors $(n=66)$ for the presence of mutations in the BRCA1 and BRCA2 genes by Illumina next-generation sequencing. Bioinformatic processing of the NGS data revealed mutations in the BRCA1 and BRCA2 genes in 39 (59.1\%) out of the $66 \mathrm{BC}$ patients. Altogether 78 unique genetic variants were detected in the study, including 30 mutations in BRCA1 and 48 mutations in BRCA2. Among all these mutations, 70 of the detected variants were identified as new mutations (89.7\%). All the detected genetic variants are listed in the Table 2.

The highest frequency in the analysis was demonstrated by the mutations 17:41246746:T>C in BRCA1 gene (52\%) and 13:32914688:G>T in BRCA2 gene (47\%). The mutation 13:32910800:A>C in BRCA2 gene occurred the most frequently among all samples, being identified in $10.7 \%$ ( $n=3 / 28$ ) of tumors with BRCA2 mutations. Mutations in both $B R C A 1$ and BRCA2 were found in 11 patients with $B C$ $(16.7 \% ; n=66)$.

Annotation against databases revealed 33 mutations $(42.3 \%)$ influencing the sequence of the coded protein, including 16 in BRCA1 gene and 17 in BRCA2 gene. The

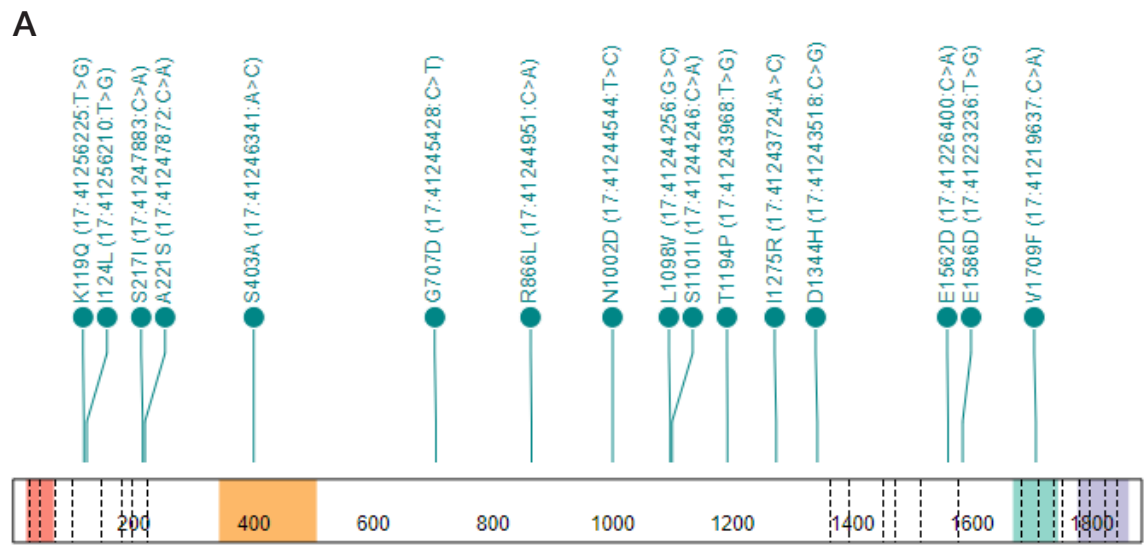

BRCA 1 NM_007300

RING

BRCT_assoc

BRCT

BRCT

B

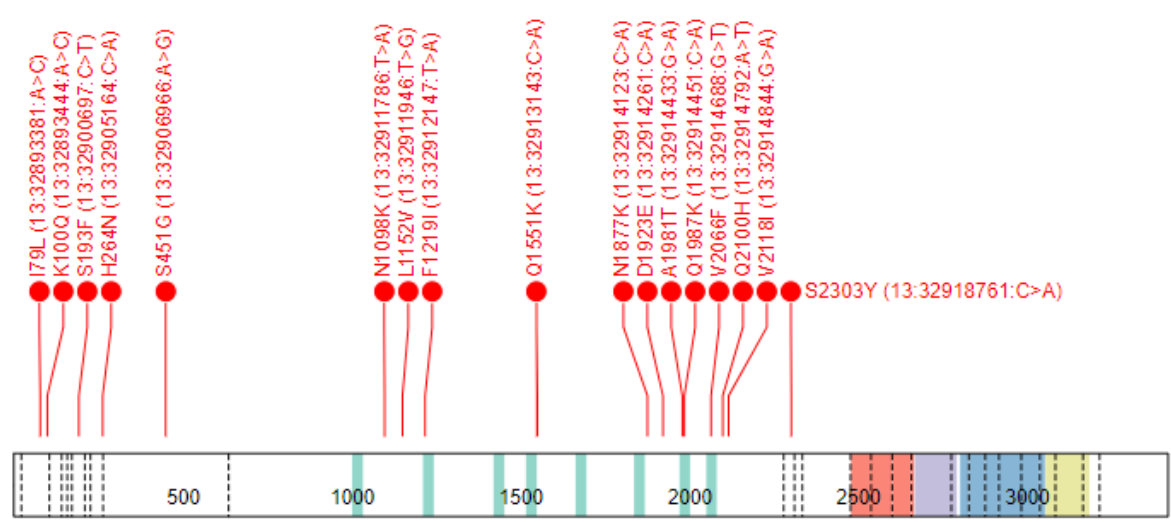

BRCA 2 NM_o00059

BRCA2

BRCA-2_helical

BRCA-2_OB1

BRCA2DBD_OB2

BRCA-2_OB3

Fig. 1. The spectrum of mutations* affecting post-translational modification sites of proteins (PMT-mutations) in the genes BRCA1 (A) and BRCA2 (B), in patients with breast cancer $(n=39)$. * - based on mutation effect prediction according to ActiveDriverDB 
Table 2. BRCA1 and BRCA2 mutations identified in patients with $B C$

\begin{tabular}{|c|c|c|c|c|c|c|c|c|c|}
\hline Gene & $\begin{array}{l}\text { Sample } \\
\text { ID }\end{array}$ & $\begin{array}{l}\text { BC } \\
\text { Stage }\end{array}$ & $\begin{array}{c}\text { The proportion } \\
\text { of cancer cells } \\
\text { in the } \\
\text { sample }^{1}, \%\end{array}$ & $\begin{array}{l}\text { Variant allele } \\
\text { frequency, \% }\end{array}$ & $\begin{array}{l}\text { Coverage } \\
\text { at the } \\
\text { point }\end{array}$ & $\begin{array}{c}\text { PTM- } \\
\text { mutation }\end{array}$ & Effect $^{2}$ & Reference number ${ }^{2}$ & $\begin{array}{c}\text { Canonical } \\
\text { designation }\end{array}$ \\
\hline \multirow{30}{*}{$B R C A 1$} & 1 & IIIA & 20 & 52 & 235 & No & None & Novel & $17: 41246746: T>C$ \\
\hline & 2 & $\| \mathrm{A}$ & 9 & 30 & 117 & No & None & rs1800744 & $17: 41226488: C>A$ \\
\hline & \multirow{4}{*}{3} & \multirow{4}{*}{ IA } & \multirow{4}{*}{70} & 4 & 106 & No & None & Novel & 17:41251858:T>G \\
\hline & & & & 3 & 115 & Yes & distal & Novel & 17:41223236:T>G \\
\hline & & & & 2 & 267 & Yes & proximal & Novel & 17:41243968:T>G \\
\hline & & & & 1 & 439 & No & None & Novel & $17: 41245560: C>A$ \\
\hline & \multirow{2}{*}{4} & \multirow{2}{*}{ I } & \multirow{2}{*}{30} & 4 & 116 & Yes & proximal & rs80357088 (dbSNP) & $17: 41247872: C>A$ \\
\hline & & & & 1 & 685 & Yes & proximal & rs80357192 (dbSNP) & $17: 41245428: C>T$ \\
\hline & 5 & $\| A$ & 8 & 4 & 230 & Yes & $\begin{array}{c}\text { network-rewiring - } \\
\text { motif loss }\end{array}$ & Novel & $17: 41244256: G>C$ \\
\hline & 6 & 1 & 90 & 2 & 169 & Yes & direct & Novel & $17: 41244246: C>A$ \\
\hline & 7 & IIA & 21 & 2 & 250 & No & None & Novel & $17: 41244207: T>C$ \\
\hline & 8 & IA & 8 & 2 & 306 & No & None & Novel & $17: 41246576: A>C$ \\
\hline & 9 & IA & 6 & 2 & 270 & Yes & distal & Novel & $17: 41243724: A>C$ \\
\hline & \multirow{3}{*}{10} & \multirow{3}{*}{ IA } & \multirow{3}{*}{32} & 2 & 142 & Yes & proximal & Novel & 17:41256210:T>G \\
\hline & & & & 2 & 142 & Yes & distal & Novel & $17: 41256225: T>G$ \\
\hline & & & & 1 & 333 & Yes & direct & Novel & $17: 41246341: A>C$ \\
\hline & \multirow{2}{*}{11} & \multirow{2}{*}{ IIB } & \multirow{2}{*}{95} & 2 & 166 & Yes & proximal & BRCA (TCGA MC3) & $17: 41243518: C>G$ \\
\hline & & & & 1 & 467 & No & None & Novel & $17: 41245516: C>A$ \\
\hline & 12 & $\mathrm{IA}$ & 98 & 1 & 202 & Yes & distal & Novel & $17: 41247883: C>A$ \\
\hline & 13 & IA & 15 & 1 & 660 & Yes & $\begin{array}{c}\text { network-rewiring - } \\
\text { motif loss }\end{array}$ & Novel & $17: 41244951: C>A$ \\
\hline & 14 & IIB & 35 & 1 & 444 & No & None & Novel & $17: 41245785: C>A$ \\
\hline & 15 & I & 12 & 1 & 569 & No & None & Novel & $17: 41245228: C>T$ \\
\hline & 16 & IIB & 12 & 1 & 351 & No & None & Novel & 17:41245832:T>G \\
\hline & 17 & $\| \mathrm{A}$ & 57 & 1 & 413 & No & None & Novel & $17: 41245859: C>A$ \\
\hline & 18 & IA & 12 & 1 & 211 & Yes & proximal & Novel & $17: 41226400: C>A$ \\
\hline & 19 & IIA & 38 & 1 & 342 & Yes & distal & rs786202665 (dbSNP) & $17: 41244544: T>C$ \\
\hline & 20 & $\| A$ & 32 & 1 & 307 & No & None & Novel & $17: 41246752: C>A$ \\
\hline & \multirow{2}{*}{21} & \multirow{2}{*}{$\mathrm{IA}$} & \multirow{2}{*}{35} & 1 & 336 & Yes & distal & Novel & $17: 41219637: C>A$ \\
\hline & & & & 1 & 379 & No & None & Novel & $17: 41246125: T>A$ \\
\hline & 22 & $\| A$ & 10 & 1 & 390 & No & None & Novel & $17: 41245026: C>A$ \\
\hline \multirow{18}{*}{$B R C A 2$} & \multirow{2}{*}{9} & \multirow{2}{*}{$\mathrm{IA}$} & \multirow{2}{*}{6} & 47 & 189 & Yes & distal & Novel & 13:32914688:G>T \\
\hline & & & & 2 & 210 & Yes & distal & Novel & 13:32905164:C>A \\
\hline & 10 & in & م & 6 & 471 & No & None & rs28897716 (dbSNP) & 13:32911295:G>A \\
\hline & 12 & $I A$ & 90 & 1 & 434 & Yes & proximal & Novel & 13:32893381:A>C \\
\hline & 23 & IA & 15 & 4 & 100 & No & None & Novel & 13:32906550:T>C \\
\hline & 24 & 1 & 50 & 3 & 63 & No & None & rs55924966 (dbSNP) & 13:32929408:G>A \\
\hline & 10 & 11 & مอ & 3 & 152 & No & None & Novel & 13:32912843:G>T \\
\hline & 19 & $11 \mathrm{~A}$ & 30 & 2 & 276 & No & None & Novel & 13:32912258:C>A \\
\hline & 25 & IA & 65 & 2 & 319 & No & None & Novel & 13:32910800:A>C \\
\hline & 14 & IIB & 35 & 2 & 316 & Yes & direct & rs864622305 (dbSNP) & 13:32900697:C>T \\
\hline & 7 & $\| A$ & 21 & 2 & 251 & No & None & Novel & 13:32944694:G>T \\
\hline & OR & in & . & 2 & 255 & No & None & Novel & 13:32911260:A>T \\
\hline & 20 & IA & 10 & 1 & 537 & No & None & Novel & 13:32910800:A>C \\
\hline & ד & 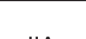 & & 2 & 87 & Yes & proximal & Novel & $13: 32918761: C>A$ \\
\hline & & & & 2 & 238 & No & None & Novel & 13:32930703:C>A \\
\hline & & & & 2 & 130 & No & None & Novel & 13:32931930:G>T \\
\hline & $\angle 0$ & HA & 10 & 1 & 307 & Yes & distal & Novel & 13:32914451:C>A \\
\hline & 29 & 1 & 1 & 2 & 262 & No & None & Novel & 13:32910800:A>C \\
\hline
\end{tabular}




\begin{tabular}{|c|c|c|c|c|c|c|c|c|}
\hline \multirow{3}{*}{30} & \multirow{3}{*}{ IIA } & \multirow{3}{*}{55} & 2 & 200 & No & None & Novel & 13:32911499:C>A \\
\hline & & & 2 & 237 & No & None & Novel & 13:32913030:A>C \\
\hline & & & 1 & 274 & Yes & distal & Novel & 13:32914261:C>A \\
\hline \multirow{3}{*}{10} & \multirow{3}{*}{ IA } & \multirow{3}{*}{32} & 2 & 99 & Yes & distal & Novel & 13:32893444:A>C \\
\hline & & & 2 & 179 & No & None & Novel & 13:32907009:T>G \\
\hline & & & 2 & 188 & Yes & proximal & Novel & 13:32911946:T>G \\
\hline \multirow{5}{*}{4} & \multirow{5}{*}{1} & \multirow{5}{*}{30} & 2 & 807 & No & None & Novel & 13:32914484:C>A \\
\hline & & & 1 & 323 & No & None & Novel & 13:32899216:G>A \\
\hline & & & 1 & 747 & No & None & Novel & 13:32915036:A>T \\
\hline & & & 1 & 279 & No & None & Novel & 13:32930596:T>A \\
\hline & & & 1 & 285 & No & None & Novel & 13:32930604:A>G \\
\hline \multirow{2}{*}{21} & \multirow{2}{*}{ IA } & \multirow{2}{*}{35} & 2 & 332 & No & None & Novel & 13:32914234:C>A \\
\hline & & & 1 & 440 & No & None & Novel & 13:32907309:C>A \\
\hline \multirow{3}{*}{22} & \multirow{3}{*}{$\| \mathrm{A}$} & \multirow{3}{*}{10} & 2 & 164 & No & None & Novel & $13: 32912375: C>A$ \\
\hline & & & 1 & 298 & No & None & Novel & $13: 32907051: A>T$ \\
\hline & & & 1 & 358 & Yes & distal & Novel & 13:32914844:G>A \\
\hline 2 & IIA & 9 & 2 & 165 & No & None & Novel & 13:32968849:T>C \\
\hline \multirow{2}{*}{31} & \multirow{2}{*}{ IIIC } & \multirow{2}{*}{18} & 1 & 405 & No & None & Novel & 13:32913099:A>C \\
\hline & & & 1 & 266 & No & None & Novel & 13:32929173:C>A \\
\hline \multirow{2}{*}{32} & \multirow{2}{*}{$\| \mathrm{A}$} & \multirow{2}{*}{9} & 1 & 526 & Yes & proximal & Novel & 13:32913143:C>A \\
\hline & & & 1 & 399 & No & None & Novel & 13:32968988:C>A \\
\hline 33 & IIIA & 10 & 1 & 233 & Yes & distal & Novel & 13:32911786:T>A \\
\hline 14 & IA & 15 & 1 & 362 & No & None & Novel & 13:32936764:C>A \\
\hline 34 & $\| A$ & 14 & 1 & 371 & Yes & distal & Novel & 13:32912147:T>A \\
\hline \multirow{2}{*}{35} & \multirow{2}{*}{ IB } & \multirow{2}{*}{5} & 1 & 246 & No & None & Novel & 13:32913558:C>T \\
\hline & & & 1 & 434 & Yes & distal & Novel & 13:32914792:A>T \\
\hline 36 & IIB & 25 & 1 & 344 & Yes & distal & Novel & 13:32914433:G>A \\
\hline \multirow{2}{*}{37} & \multirow{2}{*}{ IIB } & \multirow{2}{*}{80} & 1 & 569 & Yes & distal & rs374326934 (dbSNP) & 13:32914123:C>A \\
\hline & & & 1 & 275 & No & None & Novel & $13: 32937605: G>A$ \\
\hline 1 & IIIA & 20 & 1 & 320 & Yes & distal & Novel & 13:32906966:A>G \\
\hline 38 & 1 & 10 & 1 & 439 & No & None & Novel & 13:32913444:C>A \\
\hline \multirow{2}{*}{39} & ll & 18 & 1 & 262 & No & None & Novel & 13:32930600:C>A \\
\hline & & & 1 & 363 & No & None & Novel & 13:32936793:C>A \\
\hline
\end{tabular}

Note: ${ }^{1}$ - based on histological data; ${ }^{2}$ — based on ActiveDriverDB data (https://www.activedriverdb.org/).

mutations affecting the sites of post-translational modification in proteins (PMT mutations) are shown in the Fig. 1.

\section{DISCUSSION}

Personalized targeted therapy is gaining ground in modern oncology. The development of a highly sensitive and costefficient approach to affordable routine diagnosis of tumors is therefore a priority task.

The "gold standard" for mutation detection today is Sanger sequencing, but its diagnostic capabilities are limited compared to next-generation genetic analysis systems. Tumor cells are histologically and genetically heterogeneous, contributing to the advantage of NGS-based techniques, which allow developing efficient bioinformatics pipelines for detecting genetic variants both in pairs of tumor and normal tissues samples and within individual biopsies containing a fraction of normal cell DNA.
Mutations in the key $\mathrm{BC}$ oncogenes BRCA1 and BRCA2 are among the most frequent and significant molecular aberrations, whose analysis can help in assessing the risk of tumor development, clinical prediction for BC patients, and in predicting the effectivenesss of anticancer drug therapy.

The BRCA1 gene was identified by Y. Miki et al. in 1994 by positional cloning on the long arm of chromosome 17. The second gene - BRCA2, was mapped and isolated on chromosome 13q. BRCA1 and BRCA2 are suppressor genes, characterized by the autosomal dominant inheritance pattern and high penetrance. Recent molecular studies of BRCA1 and $B R C A 2$ have demonstrated a wide spectrum of mutations present in these genes [5].

The international COSMIC database [11] contains over 900 somatic coding mutations of the BRCA1 gene and over 1400 coding mutations of the BRCA2 gene. A substantial part of these mutations result in structural transformations modifying 
the function of protein products, thus undermining the capacity of repair systems to effectively fix DNA lesions. Many of the mutations in BRCA1/BRCA2 are missence mutations, where the coding sequence is altered and one functional codon is changed to another.

Having analyzed the NGS data for the BC tumors in our study by bioinformatics techniques, we identified 78 unique mutations in the genes BRCA1 and BRCA2. A majority of the mutations were found in BRCA2. According to the literature, the frequency of mutations differs notably between the genes BRCA1 and BRCA2 [5]

Further analysis using ActiveDriverDB showed that a large part of the genetic variants produce a functional effect on posttranslational modification sites of the coded proteins (Fig. 1). Our study revealed 33 PMT-mutations, many of them previously unannotated. To confirm the pathogenic variants detected in the study and the status of the mutations, the research results need to be verified by Sanger sequencing using normal tissue samples.

\section{CONCLUSIONS}

Targeted next-generation sequencing appears to be the most promising approach for molecular profiling of tumors for clinical application. An integrated NGS-based analysis of mutations in the genes BRCA1 and BRCA2 in BC patients enables the identification of a greater number of mutations, including low mutant allele frequency variants, as well as genetic variants in biopsy samples with low tumor cell content. NGSbased approaches revealing mutations in the entire BRCA1 and BRCA2 coding sequence will enable a more effective identification of the patients to whom an adequate therapy with targeted anticancer drugs can be administered.

\section{References}

1. Bejsebaev EN. Sovremennye sravnitel'nye aspekty jepidemiologii raka molochnoj zhelezy. Vestnik KazNMU. 2014; (1): 78-83.

2. Ferlay J, Soerjomataram I, Dikshit R, Eser S, Mathers C, Rebelo M et al. Cancer incidence and mortality worldwide: sources, methods and major patterns in GLOBOCAN 2012. Int J Cancer. 2015; (136): E359-86.

3. Tao Z, Shi A, Lu C, Song T, Zhang Z, Zhao J. Breast Cancer: Epidemiology and Etiology. Cell Biochem Biophys. 2015; (72): 333-8.

4. Ghoncheh M, Pournamdar Z, Salehiniya $H$. Incidence and Mortality and Epidemiology of Breast Cancer in the World. Asian Pac J Cancer Prev. 2016; (17): 43-6.

5. Bykova AV, Vorotnikov IK, Vishnevskaja JaV, Denchik DA, Ljubchenko LN. Rol' mutacii genov BRCA 1 i BRCA 2 v vozniknovenii raka molochnoj zhelezy u muzhchin. Opuholi zhenskoj reproduktivnoj sistemy. 2011; (1): 29-31.

6. Giuliano AE, Connolly JL, Edge SB, Mittendorf EA, Rugo HS, Solin LJ et al. Breast Cancer-Major changes in the American Joint Committee on Cancer eighth edition cancer staging manual. CA Cancer J Clin. 2017; 67 (4): 290-303.

\section{Литература}

1. Бейсебаев Е. Н. Современные сравнительные аспекты эпидемиологии рака молочной железы. Вестник КазНМУ. 2014; (1): 78-83.

2. Ferlay J, Soerjomataram I, Dikshit R, Eser S, Mathers C, Rebelo M et al. Cancer incidence and mortality worldwide: sources, methods and major patterns in GLOBOCAN 2012. Int $\mathrm{J}$ Cancer. 2015; (136): E359-86.

3. Tao Z, Shi A, Lu C, Song T, Zhang Z, Zhao J. Breast Cancer: Epidemiology and Etiology. Cell Biochem Biophys. 2015; (72): 333-8.

4. Ghoncheh M, Pournamdar Z, Salehiniya $H$. Incidence and Mortality and Epidemiology of Breast Cancer in the World. Asian Pac J Cancer Prev. 2016; (17): 43-6.

5. Быкова А. В., Воротников И. К., Вишневская Я. В., Денчик Д. А., Любченко Л. Н. Роль мутации генов BRCA 1 и BRCA 2 в возникновении рака молочной железы у мужчин. Опухоли женской репродуктивной системы. 2011; (1): 29-31.

6. Giuliano AE, Connolly JL, Edge SB, Mittendorf EA, Rugo HS, Solin LJ et al. Breast Cancer-Major changes in the American Joint Committee on Cancer eighth edition cancer staging manual. CA Cancer J Clin. 2017; 67 (4): 290-303.

7. Cukanov KJu, Krasnenko AJu, Korostin DO, Churov AV, Stecenko IF, Plotnikov NA i dr. Rak molochnoj zhelezy: analiz spektra somaticheskih drajvernyh mutacij s primeneniem vysokoproizvoditel'nogo sekvenirovanija. Vestnik RGMU. 2017; (6): 52-8.

8. Cukanov KJu, Krasnenko AJu, Plahina DA, Korostin DO, Churov AV Druzhilovskaja O. S. i dr. Bioinformaticheskij protokol dlja obrabotki NGS-dannyh i identifikacii mutacij v solidnyh opuholjah cheloveka. Biomedicinskaja himija. 2017; 63 (5): 413-7.

9. Krassowski M, Paczkowska M, Cullion K, Huang T, Dzneladze I, Ouellette BFF et al. ActiveDriverDB: human disease mutations and genome variation in post-translational modification sites of proteins. Nucleic Acids Res. 2018; 46: D901-D910.

10. Zhou X, Edmonson MN, Wilkinson MR, Patel A, Wu G, Liu Y et al. Exploring genomic alteration in pediatric cancer using protein paint. Nat Genet. 2015; (48): 4-6.

11. Forbes SA, Beare D, Bindal N, Bamford S, Ward S, Cole CG et al. COSMIC: High-Resolution Cancer Genetics Using the Catalogue of Somatic Mutations in Cancer. Curr Protoc Hum Genet. 2016; (91): 10.11.1-10.11.37.
7. Цуканов К. Ю., Красненко А. Ю., Коростин Д. О., Чуров А. В. Стеценко И. Ф., Плотников Н. А. и др. Рак молочной железы: анализ спектра соматических драйверных мутаций с применением высокопроизводительного секвенирования. Вестник РГМУ. 2017; (6): 52-8.

8. Цуканов К. Ю., Красненко А. Ю., Плахина Д. А., Коростин Д. О., чуров А. В., Дружиловская О. С. и др. Биоинформатический протокол для обработки NGS-данных и идентификации мутаций в солидных опухолях человека. Биомедицинская химия. 2017; 63 (5): 413-7.

9. Krassowski M, Paczkowska M, Cullion K, Huang T, Dzneladze I, Ouellette BFF et al. ActiveDriverDB: human disease mutations and genome variation in post-translational modification sites of proteins. Nucleic Acids Res. 2018; 46: D901-D910.

10. Zhou X, Edmonson MN, Wilkinson MR, Patel A, Wu G, Liu Y et al. Exploring genomic alteration in pediatric cancer using protein paint. Nat Genet. 2015; (48): 4-6.

11. Forbes SA, Beare D, Bindal N, Bamford S, Ward S, Cole CG et al. COSMIC: High-Resolution Cancer Genetics Using the Catalogue of Somatic Mutations in Cancer. Curr Protoc Hum Genet. 2016; (91): 10.11.1-10.11.37. 